\title{
Soul-Ravishing and Sin-Subduing: Anna Trapnel and the Gendered Politics of Free Grace
}

\section{HILARY}

HINDS

Résumé : Le présent article analyse l'œuvre de la prophétesse et « cinquième monarchiste » Anna Trapnel par rapport à la doctrine de la grâce libre, toujours une notion centrale du Protestantisme qui acquit une importance et une inflexion particulières dans les années 1640 et 1650. Il est proposé que la souplesse de ce concept, ainsi que son orthodoxie indubitable dans l'optique de la Réforme, ont permis à Trapnel de représenter la matérialité du corps prophétique avec ses désirs, non pas comme des entraves, mais comme les signes glorieux de l'intervention divine.

"Free grace, and nothing but free grace makes us to differ from others": with these words, both celebratory and uncompromising, the Fifth-Monarchist prophet Anna Trapnel claims free grace as a touchstone in the business of spiritual and sectarian reflection and identification. ${ }^{1}$ On the one hand, her statement suggests the fundamental mystery of the distinction between the elect and the reprobate, those in a state of grace and those excluded from it. On the other hand, and equally importantly, it underlines the primacy of the issue of free grace for questions of sectarian self-definition and - a related issue - the differentiation of one sectarian position from another. Of all her writings, A Legacy for Saints (1654), from which these words are taken, is the most concerned to establish Trapnel's spiritual credentials. ${ }^{2}$ These are established through the tracing of her own spiritual trajectory, which, in turn, is in large part dependent upon her interpretation of the doctrine of grace and her positioning of herself in relation to it. References to free grace are thus fundamental to Trapnel's accounts, not only of what she believes, but also of who she is, where she belongs, and what she does. 
In the light of the repeated and ineluctable return to the concept of free grace in Trapnel's writings, as to something compelling in its capacity to exceed definitive textualisation, it is striking how little of the recent critical attention to Trapnel's work has engaged the religious or, more specifically, the doctrinal issues which informed sectarian debate and helped constitute sectarian identity. ${ }^{3}$ Whilst critics have focused on the manner in which Trapnel negotiated prohibitions against female authorship, or argued that the body of the female prophet "spoke" as loudly as the words she uttered, there has been little discussion of the ways in which hotly contested issues concerning doctrine and practice inflected her writings, or of the implications of these issues for the politics, whether sectarian or more broadly cultural, of her activities and writings. ${ }^{4}$ In this article, therefore, I propose to look at one such issue - namely, the question of free grace - and consider how this figures both in Trapnel's own writing and in broader sectarian debate, and at the ways in which a consideration of this dimension might inflect the analysis of the gendering of Trapnel's work developed by critics over the past decade or so.

Free grace - not the concept itself, but rather its precise meaning, and the limits of its application - was one of the defining issues of seventeenthcentury religious history, not only within sectarian belief and practice, but also within Protestantism per se. It constituted a dimension of the debate amongst Arminians, orthodox Calvinist Puritans, and antinomians, and mapped onto the related questions of election and reprobation, the place of works in the life of the Christian and the implications of this for the question of free will, and debates about what constitutes a justifying faith and the relationship of this to sanctification. ${ }^{5}$ Just as these questions had been debated within the Church of England itself for many decades, and are seen by some historians as fundamental to the dynamics that ultimately resulted in civil war in the 1640s, so the debates continued in the many radical religious sects, which, despite often having their origins well before the 1640 s, at this point proliferated and began to attract vastly increased numbers. ${ }^{6}$ These issues, amongst others (such as the place of ordinances, particularly baptism, and of the ministry, the true location of a "church," the status of a congregation, and so on), proved to be the fault lines that separated one grouping from another, and were thus instrumental in the complicated and highly nuanced processes of self-definition undertaken in the writings emanating from these sects.

The doctrine of grace - that is, "a vision of the divine-human relationship as based on the gratuitous mercy of God in the absence of human deserving, with humankind the object of a supernatural renovation worked only by the divine favor" - had been a cornerstone of Protestant theology 
from the outset of the reformed movement. ${ }^{7}$ Indeed, "[t]he gratuity of salvation" constituted what Wallace has called "the basic Reformation insight": justification and salvation were by grace and through faith alone, not dependent on any desert of the believer. ${ }^{8}$ Salvation is thus "free," in that it is separated from any intrinsic, acquired or willed characteristic of the Christian believer and unconditionally and freely bestowed by God. From the outset, the doctrine of grace was understood to have soteriological implications, in that it was imbricated with the related doctrine of predestination. If grace was freely given and unmerited, then election, in turn, could not be tied to any notion of merit, but could only be another manifestation of God's grace, as evidenced in a justifying faith and the subsequent "sanctification" of the elect believer. Wallace has demonstrated how early the connection between grace, election and salvation was articulated in English Reformed theology, citing Thomas Becon, who, during Edward VI's reign, wrote that "our whole salvation dependeth not of any external work, but of the free election and undoubted grace of God," and the Forty-Two Articles of 1553, which stated that "predestination is related to the free grace of justification, and also to sanctification." 9

It was the implications of the relationship of grace to sanctification and salvation that proved most fraught in subsequent decades. The clearest set of debates and differences can be traced through the early seventeenth-century development of Arminianism, which argued for the reinstatement of a notion of human agency in the processes of faith and salvation: "Although God predestines, and likewise gives grace sufficient for the achieving of faith, the final ground for Arminius was still the human choice. Some avail themselves of grace and some do not, and God's eternal predestination rests upon a foreseeing of those human acts." 10 This was refuted by the orthodox Calvinism represented at the Synod of Dort in 1619 (whose conclusions were fully accepted, at this point, by the Church of England), which reaffirmed the doctrine of unconditional predestination: that is, absolute divine sovereignty in matters of salvation, and the consequent irrelevance of human works and will. Later, however, under Archbishop Laud, Arminianism gained ground within the Church of England, challenging the "arbitrary grace of predestination with a new-found source of grace freely available in the sacraments, which Calvinists had belittled," and more orthodox Calvinist notions of predestination became increasingly associated with Puritanism in its many forms. ${ }^{11}$

Throughout the 1640s, the issue of grace continued to be one around which the increasingly numerous and vociferous sects coalesced and defined themselves. Most, but not all, sectaries continued to subscribe to Calvinist doctrines of election and predestination. The Baptists, for example, divided 
around this issue, the General Baptists arguing for an Arminian doctrine of general and universally available grace, whereby saving grace was offered to all who accepted it through faith, whilst the Particular Baptists "remained true to Calvin's doctrine that Christ had died to save only particular individuals, the predestined elect." 12 McGregor argues that the discourse of "free grace" had a particular resonance through the 1640s, as Calvinists of all shades, both within the Church of England and in the sects, sought to distance themselves from the inroads made into the doctrine of predestination in preceding decades:

Free grace was a reaction against the qualification of the strict determinism of Calvinist doctrine by late Elizabethan Puritan casuists, most notably William Perkins. Their federal covenant theology allowed the desire for grace as evidence of sainthood, suggesting that faith preceded grace, but obliged the saint to demonstrate the gift of grace through Christian conduct. Free grace was a rigorous restatement of the simple logic of predestined election. It was free in being unearned and unconditional: prior worthiness and subsequent conduct were irrelevant. The consequence of sin was effectively removed since while the saint might transgress in the flesh, he remained one of the elect.

... Free grace offered a secure, uncomplicated relationship with God, which inspired self-confidence in times of crisis. Restrained by sect discipline and literal obedience to scriptural precepts, it was neither immoral nor anarchic in its consequences. In 1650, however, the Ranters reduced Scripture to a dead letter and revealed the antinomian implications of free grace. Inspired by the divine spirit, they could not sin, for then it were God sinning. What was sin to the unredeemed creature was to the Ranter an act of pure holiness. ${ }^{13}$

McGregor's narrative offers a valuable overview of the history, development and significance of the doctrine of free grace in the 1640s, and its ultimate extension into the extreme antinomianism of the Ranters. His suggestion, however, that free grace was a "rigorous statement of the simple logic of predestined election", and thus dependent on a broadly Calvinist theology, significantly underplays the breadth of doctrinal affiliation with the notion. It was, in fact, a concept that had a far wider currency than this account allows; indeed, it is invoked across the whole spectrum of theological positions at this time, from predestinarian Calvinist to generalist Arminian. One of the best-known expositions of the concept came from the antinomian John Saltmarsh in his Free Grace: or the Flowings of Christs Blood free to Sinners, first published in 1645 , but already running to six editions by 1649. Saltmarsh notes that "The Arminians boast themselves to be as great Patrons of Free-grace as others. . . . the Papists boast of Free-grace. ... So as surely there is some other way of carrying Free-grace, then by joyning men so into the work." 14 His own definition, arrived at through the refusal of others' claims to the concept, articulates an ultra-Cal- 
vinist position that denies any conditionality to the bestowing of grace and that argues that the elect are not under the Law at all (hence the "antinomian" nomenclature), but exist in the liberty of grace, where sin has been obliterated by Christ's sacrifice. ${ }^{15}$ Thus his emphasis, characteristically "antinomian," is on "the role of God's overwhelming grace and the working of the divine Spirit in life's transformation from the old to the new. Salvation is entirely by God's act, and thus there is no place for human effort, or even for human participation." 16 The concept of free grace was also espoused by orthodox Calvinists, such as the Westminster divine Thomas Gataker, in his Antinomianism Discovered and Confuted: and Free Grace as it is held forth in Gods Word (1652), written in defense of his own interpretation of the doctrine and in answer to Saltmarsh's text. Gataker objected to Saltmarsh's obliteration of the role of human participation in the working of grace, and concludes that, if Saltmarsh's premises are accepted, "men may be saved, whether they repent or no, tho they never turn to God, or persist in a lewd and loose cours of life. ..."17

As Saltmarsh notes, however, free grace was also claimed by those rejecting Calvinist notions of election and advocating instead a doctrine of general redemption, such as the General Baptist Thomas Lambe, in his pamphlet The Fountaine of Free Grace Opened (1645). ${ }^{18}$ Here, in contradistinction to Saltmarsh's formulation of the doctrine, we have "a cautious statement of the Arminian criticism of orthodox Calvinism." ${ }^{19}$ Lambe insists on recognizing a limited area of human responsibility: namely, refusing the message of Christ's sacrifice being for all humanity, which "opposing, dispising, or neglecting is wholy mans evill work," whilst "the receiving, esteeming, or improving the same power must be considered to proceed from the covenant itself originally, and not from man, it must needs therefore be attributed to God only. . .."20 The Arminian Independent minister John Goodwin, too, claimed free grace as an integral part of his doctrine, and indeed held two debates with the Independent (later Baptist) Fifth Monarchist John Simpson at Allhallows the Great in February 1650. ${ }^{21}$ Simpson's position was that too much stress was being placed on works as preparation for grace "to the detriment of free grace." 22 Goodwin, for his part, sought to defend himself against "an undue aspersion cast upon him; as (viz.) That he held Free-will in opposition to Free Grace"; his self-defense rests on his statement that "I clearly hold, and have upon all occasions constantly taught ... [t] hat the whole plot or counsel of God concerning the Salvation of the World, is of free grace, of meer Grace, and goodness of Will, or pleasure in God." 23 Free grace, then, was so fundamental a tenet of reformed belief that the whole spectrum of English Protestants, from Arminians to orthodox Calvinists to antinomians, claimed the concept as their own. Whilst free 
grace might be a common currency, however, its meanings and its limits were fiercely contested; consequently, the concept could be deployed as the cornerstone of a bewilderingly wide range of fundamentally opposed positions, as writers and preachers, sectarian and orthodox, Arminian and antinomian, sought to put their own interpretative and doctrinal stamp upon it. It was thus a concept that crossed sectarian and doctrinal boundaries and, at the same time, was made instrumental in asserting, establishing and reinforcing those boundaries.

The 1650 debates between the Fifth Monarchist Simpson and the Arminian Goodwin signal that for Fifth Monarchists, as for the Baptists and Independents from whom they were principally drawn, free grace was a defining, and clearly also a legitimizing, term. ${ }^{24}$ Nor was this work of definition and legitimization the preserve only of Fifth Monarchist men, such as Simpson, Feake or Powell. The high profile of Anna Trapnel in the movement at this time - in 1654 she fell into a prophetic trance in Whitehall for eleven days, traveled with the backing of her congregation on an evangelizing mission to Cornwall, was arrested and imprisoned, and published four texts in her own name - underlines the point that the conventional gendered demarcations between a public and political masculine world and a private feminine one ceased to operate in the sectarian context. Trapnel was herself an active member of the Baptist/Fifth-Monarchist congregation at Allhallows the Great, where the Simpson-Goodwin debates took place. Although she does not write about these debates, they were clearly only the most public stagings of the continuing struggle for ownership of the doctrine of free grace, a struggle to which her own publications also testify. John Simpson, a lecturer at Allhallows the Great, was an important figure in Trapnel's spiritual self-narrative, and, indeed, she credits him with her conversion on 1 January $1642 / 3 .{ }^{25}$ In early 1654, after her Whitehall prophecies, Trapnel was still closely aligned with Simpson, visiting him and Christopher Feake in prison in Windsor Castle before embarking on her journey to Cornwall, and writing to them when she was herself imprisoned later that year. ${ }^{26}$ However, this allegiance to Simpson does not permit an assumption that Trapnel's theological position necessarily coincided with his, since Fifth Monarchism was unusually inclusive doctrinally. Although most adherents were predestinarian Calvinists, drawn principally from among the Baptists and Independents, and generally seeking to eschew the ultra-Calvinism of antinomianism because of its refusal of any place for the "Law" in saints' lives, there were also some General Baptists in the movement. ${ }^{27}$ To determine Trapnel's particular delineation of the term, then, we need to turn to her own writings, and in particular to her Legacy for Saints, for whilst this text has received the least critical 
attention, it offers the most detailed exposition of her doctrinal history and beliefs. $^{28}$

Fifth Monarchists might, like Saltmarsh before them, have sought to distance themselves from the pejorative associations of the term "antinomian," but Trapnel's own formulation of the doctrine of grace was clearly close enough to antinomianism for the accusation to have been made against her. She was quick to counter charges that her emphasis on the power of Grace over Law led to a Ranter-like licentiousness: "though many that cryed down free grace as a doctrine of liberty to sin, I found no doctrine so striking at my sins as it." 29 The focus of such accusations was Trapnel's antinomian privileging of Grace over Law, and her claims for the radical consequences of this for the sinfulness of the elect believer: as God tells her at one point, "Sin shall not have dominion over thee, for thou art not under the Law but under Grace". ${ }^{30}$ Similarly, in her account of the period following her conversion by Simpson (himself associated with antinomianism in the 1640s), she writes:

now I looked on the Law and legall precepts with an Evangellical eye, whereas before the light of the spirit came, I turned Gospel into Law, but now appeared a harmony between both; a Law within me, not making void that without me, but now was given me a help meet, in beholding morall precepts in Evangellical arms, Sinai's voice in Sions breast, now frowns are gone, and smiles are come, thunder is fallen, and the still voice is risen, death under, life in the top, which crown sin nor Satan can never deprive Saints of, for Saints are not under legall precepts, but under Gospel commands, and in this sense they are dead to the Law by the life of Christ in them.

And for this tenent of truth, I passed under the name of Antinomian, but praised be the Lord I was not one by adherency, though by imputation. . . 31

The status of the Law within Trapnel's theology, and in particular her argument that, post-justification, it is superseded, or subsumed, by grace, was clearly close enough to antinomianism to warrant extended discussion and analysis in a bid to differentiate herself from this widely castigated position. Her spiritual credentials, carefully set out in A Legacy for Saints, are dependent on her interpretation of the doctrine of grace, involving not only a careful exposition of her own theological position, but a series of explicit refutations of those of others: not only antinomians and Ranters, but Familists and (though she does not name them in her 1654 texts) Quakers. ${ }^{32}$ Not only do Trapnel's texts set out her political allegiances and hostilities, and in particular her disavowal of Cromwell, as he became Protector, but they also make quite clear how important the distinctions and differences between sects were. Far from there being a common sectarian religio-political stance, there were deep divisions, which coalesced as much around 
doctrinal as political questions - none, it seems, more central than that of free grace.

In this passage, then, and indeed throughout the Legacy, Trapnel works to establish her own interpretation of free grace and seeks to demonstrate its distinction from one that might be castigated as "antinomian." What, though, is at stake, in this extended, and apparently contentious, reclamation of the concept? If she rearticulates here a definition of free grace that revives (even if only to refute) the defamatory spectre of antinomianism, we might ask why this price is worth paying. What discursive possibilities are produced by means of Trapnel's formulation? And in particular, to relate this to an issue that has exercised recent critics of Trapnel, what are the implications of free grace for the gendering of the figure and utterances of the female prophet?

For Trapnel, her accession to the free grace of God is inseparable from her accession to the status of visionary prophet. ${ }^{33}$ Whilst not all those in a state of grace are prophets, the reverse $i s$ the case: the power of prophecy is precisely dependent on the sainthood and the accession to grace of the prophet, and this must be seen to be true if the prophetic utterance is to be accepted as such. Trapnel's first truly heavenly visions follow shortly after her conversion by Simpson. As he spoke, she writes, "suddenly my soul was filled with joy unspeakable," as she finally apprehended the full meaning of the imputation of Christ's righteousness: her sins were sacrificed with Christ, and she experiences herself as the recipient of his sinlessness ("I apprehended nothing but a clothing of glory over my whole man"). ${ }^{34}$ In the time following this, during "this year in which I was new-born", she writes, "some days and nights I had feasts full of marrow, and visions full of glory": "In the night before sleep had seized upon me, a bright light shined round my head visible and in the midst of that light stood one all in white, in the likeness of a creature all covered with brightness ... . [I] was bid by the inward speaking of the spirit not to fear, for I had seen an Angell." 35 Her capacity to prophesy followed later: included in A Legacy for Saints is a prophetic piece written in 1646, preceding a period of serious illness and at a time when she was troubled with spiritual doubts and temptations. ${ }^{36}$ Whatever the precise timing, the sequence is clear: to be "in the visions of God," to be able to gain access to the divine Word through prophecies, dreams, visions and trances, one must, by definition, be sanctified ${ }^{37}$ Prophecy is subsequent to and dependent on grace.

If the accession to grace is transformative, opening the saint to the power of prophecy, then what, we might ask, is the nature of this transformation? What is the "matter" which is acted upon by grace, and what is the nature of the effect in relation to the resulting prophetic power? Important, 
without doubt, is the "antinomian" stress on the irrelevance of the will of the human subject in this process. Many critics have noted the importance of discourses of feminine weakness in the writings by women in the radical sects, and the coupling of this with denials of any self-will or agency in the production of their own writings: as Trapnel wrote, "thy servant is made a voice, a sound, it is a voice within a voice, even thy voice through her." 38 The ultra-Calvinist stress on the utter inability of the believer to initiate, or participate in, matters relating to their own salvation provided a clear doctrinal underpinning to these discourses of feminine incapacity. Indeed, the gendered structure implicit in this characterization has been made explicit in the work of one critic, Leo Solt, who likened the antinomian apprehension of the position of the elect Christian in relation to God to that of "an abducted maiden. The maiden's fear would have been converted by her abductor's love to faith, and her startled incredulity at her own abduction would have changed to an assuring belief that it had really happened and was not just a wishful dream." 39 Solt's formulation of this gendered analogy suggests the fundamental importance and absolute character of the powerlessness of the believer in the antinomian inflection of this Calvinist orthodoxy.

What does not figure in Solt's characterization, however, is any sense of how the feminine powerlessness apparently guaranteed by the gendered structuring of this relationship might be turned to account by women writers having to justify their access either to authorship or to the subject-position of "prophet." Diane Purkiss, however, has offered a series of analyses of the discursive moves by which Trapnel effects this transformation, noting the manner in which the powerful positions from which Trapnel's prophecies are spoken are produced through the mobilization of a range of gendered discourses of corporeal self-denial, in particular through fasting. Hereby, Purkiss argues, "the female body is a sign from which female agency is evacuated," with the effect that, at least momentarily, "gendered subjection was confined to the disavowed flesh, while the escaped spirit had freedom," a freedom that authorized the prophecies that she proceeds to produce. ${ }^{40}$ The body, without doubt, is a key signifier in Trapnel's prophetic and autobiographical texts, and Purkiss is right to draw attention to the way in which it is repeatedly assaulted, abased or denied, so as to make way for the divinely originating words that can be uttered consequent to its dissolution: "Vision! The body crumbles before it, and becomes weak ... they that have flowings of thee, are self-denying"; "Oh what is the carcass, the vessel? They are nothing, but when these are gone, then where am I, but there where I am made perfect in thy self." 41 The battering of her body through her life-threat- 
ening illness of 1646 is only the sharpest and most literal exposition of many such assaults on the body in the service of the elevation of the spiritual self.

However, there is a further dimension to the invocation of the body in Trapnel's writing, which complicates the sense that the body, inscribed as it is by the gendered inequalities of the social, is abased and denied, so that the "escaped spirit" can exercise its ungendered powers free of its corporeal trammel. For the discourse of free grace, I would argue, not only emphasizes the spiritual dimension of the believer's sanctification but also effects the revaluation of the believer's body: as she writes in A Legacy, "the creature can never learn the lesson of humiliation and self-denial, till it hath been in the School of free grace." 42 A state of grace, for Trapnel, is by no means a disembodied one; on the contrary, her writings suggest that it is to be understood only in the most bodily of terms. Indeed, during her 1646 illness Trapnel is gently chastised by her divine interlocutor when she longs for release from her bodily affliction:

I desired rather to be out of the body then in it, and when I breathed forth to God how I should live in the body, it was answered me, to the glory of thy God, is not my grace sufficient for thee? and art thou afraid to live in the body for fear of the strength of corruptions? Sin shall not have dominion over thee, for thou art not under the Law but under Grace ... ${ }^{43}$

Grace, Trapnel is told here, eliminates bodily corruption, and ought therefore to reconcile the saint to life in the body. Moreover, shortly after this passage, spiritual salvation is itself figured through the bodily redemption effected by God in relation to her illness: "at that instant God told me my breath should be given me." 44 Accession to God's grace, far from erasing the significance of the body, transforms it by bringing the body to a state whereby "sin shall not have dominion over thee" (by the imputation of Christ's perfection, by which "I am made perfect in thy self"). ${ }^{45}$ As she writes in A Legacy, "Oh let sinners admire free grace with me, that hath freed me from as stony, as seared, benummed, sensless a condition, as any could or can be in; hearing or reading, or Saints speaking to me, was as to one deaf. ..." 46 Free grace unfreezes the body's senses, accords them new sensitivities and new capacities; through grace, she can feel, see and hear as never before. The body itself hereby comes to have a kind of divine signification, not just as an earthy hindrance that crumbles away, but as yet another marker of the power of God's grace to transform and transvalue. ${ }^{47}$ Trapnel might assert that "to speak of my body was but lost time," yet her writings make clear the signifying capacity of her body, its ability to be remade through the act of divine grace, and thus its importance to the bringing into being of the prophetic subject. ${ }^{48}$ 
It is not only in illness, however, that the body makes its presence felt. Throughout the detailed exposition in A Legacy of Trapnel's own journey through the highly conventional order of salvation (the Ordo Salutis), we are repeatedly returned to a blissfully corporeal vision of the state of grace. ${ }^{49}$ The joyful implications of the transition from Law to Gospel effected through the accession to grace (seen in the passage from A Legacy, pp. 14-15, quoted above) are expressed in biblically conventional terms, in which, as Grace supersedes Law, so the bridegroom Christ displaces the patriarchal law-giver Moses: "the Saint that is throughly spiritual, loves dearly to walk inclosed in the arms of its Saviour, and to be imbraced by him, and kissed with the kisses of his mouth, for his love is better than wine. . . "50 Citing here the Song of Songs $(1: 2,2: 6,4: 10,12,8: 3)$ to characterize the relationship of the saint with the savior in a state of grace, Trapnel taps into long-established readings of this book of the Bible, whose erotics had been variously understood within the Christian tradition as an allegory of the individual soul's union with Christ, of Christ's love for his Church, and of the apocalypse. ${ }^{51}$ Drawing on this common stock of associations, as had many women visionaries before her, Trapnel's use of the image underwrites the figuring of the joy of the saint's union with Christ through grace as erotic, and specifically endorses the bodiliness of the pleasures that follow from this, placing them in comparative relation with other bodily pleasures. ${ }^{52}$ As she seeks to convey the raptures of free grace, she relies on frankly, and perhaps surprisingly, carnal imagery: free grace is a "salve drawing out corruptions and ill humors"; she found "no plaister healing the most desperate wound, like the plaister of free grace; its cleansing physick, it runneth between the marrow and the bones"; Christ is "tender mother," but also "Comforter," bringing "love tokens to my soul, and setting before me varieties of dishes at every bankquet, for a year together, my meat was sweet meats from heaven, my drink wine upon the lees, wines well refined, milk and hony was my ordinary dish ...." 53 Free grace first remakes the spiritual body, then indulges it, instating a kind of spiritual Cockayne in which appetites are sated by a divinely originating abundance figured as fully material. The state of grace - and indeed Trapnel's trances, too, which body forth this state — are "Soul-ravishing," as well as "Sin-subduing". 54

Free grace might necessitate the dissolution of the corrupt body that characterized life under the Law; Grace itself, however, does not obviate the body, but transforms and satisfies it. As Sharon Achinstein has argued, sectarian and nonconformist spirituality allowed women writers to produce themselves as desiring subjects in powerful and far-reaching ways. ${ }^{55}$ This is undoubtedly the case in Trapnel's work. More specifically, however, I would suggest that it is the conjunction of the discourse of free grace with 
the spiritualized erotics of the Song of Songs that provides Trapnel with a dynamic language for rewriting and reclaiming the prophetic body. Thereby the body is empowered, transformed from object to subject, instrument to agent, as the fears of the body under Law are replaced by the desires of the body under Grace. The imagery from the Song of Songs, as Achinstein suggests, rewrites the divine-human relationship; in the case of Trapnel, it transposes it from the rigid hierarchy of the patriarch-subject relation to the more ambiguous one of the beloved and the bridegroom. Initially, this might be expected to underline the hierarchy of that relationship by figuring it in explicitly gendered terms, feminizing the position of the believer in relation to Christ. But rather than confirming the inferiority of the feminine subject position, this moment instead imbues that subject position with power. Christ is, after all, figured here as bridegroom, the saint or church as the bride. Both are liminal positions, in the interstices between suitor and husband, betrothed and wife; both presuppose the recognition and ritualization of a moment of impermanence and transformation. ${ }^{56}$ Such associations are drawn out not only by prophets such as Trapnel, but more generally in the religious discourse of her contemporaries. ${ }^{57}$ William Greenhill, for example, an Independent minister and, moreover, one of Trapnel's visitors during her trance in Whitehall, gives a strong sense of the power of the image of the bride in his sermon on Revelation 22:17 (a text that is key to readings of the Song of Solomon as an allegory of Christ's relationship with his church), "And the Spirit and the Bride say, Come":

The marriage of the Lamb is come; Then shall bee the marriage, now it is a Bride. But then shall be the Marriage, then shall we rejoyce, for the marriage of the Lamb is come, and his Wife hath made her self ready. There will bee more intimate and sweet communion; then will Christ let out his loves to the Soul indeed - Then will he lead his Spouse, his Bride, his Wife into the Marriage Chamber, into the Wineseller. ... 58

For Greenhill, as for Trapnel, the promise condensed in the image is bound up in its futurity, but also in the absolute certainty and imminence of its fulfillment, underlined through the trochaic resounding of the phrases "then shall" and "then will" throughout the passage. The relation is in flux - "Then shall be the marriage, now it is a Bride" — as is the female figure herself: she is at once, or serially, "his Spouse, his Bride, his Wife." For Greenhill, as for Trapnel, the image of the bride and bridegroom, poised between two subject-positions and two social identities, serves as a matrix of expectation and certainty, of imminence and deferral. ${ }^{59}$

Both bride and bridegroom share these associations of transformative liminality; however, beyond this there is a distinctive gender dimension to 
the relation, which is of significance to Trapnel's text. It draws on a moment which might arguably be seen as one of the few culturally endorsed instances of feminine empowerment, namely, the period of courtship and betrothal, when, whilst being the object of desire, the woman is also able, precisely because of that desirability, to make demands upon the male. Such an analysis is made most readily with regard to cultural representations, such as Shakespeare's comedies, where the female protagonist often exploits and enjoys the energies and possibilities produced by a heterosexual relation structured in relation to the woman as both desiring and desired. Just as in those plays, this equilibrium is not translated into the post-marital moment, when, structurally, that social and cultural power is relocated with the husband, as the empowered feminine subject of romantic love is refocused as the object of masculine exchange. So, too, here, in the imagery drawn from the Song of Songs, the beloved saint remains in the highly charged and potent position of both desiring and desired, of yearning for satiation and yet also poised in a position of absolute and assured anticipation of its imminence: as the Song of Songs succinctly puts it, "I am my beloved's, and his desire is toward me" (7:10). This dynamic of endlessly perpetuated desire and satiation structures Greenhill's text, too, in such a way as to suggest the importance of the gendering of this relation to contemporary commentators:

The Church is sick of Love for Jesus Christ, and earnestly desires his coming - such a desire as is in Women with Childe, that miscarry if they have not their desire-such a desire as is in the captive to bee delivered-such a desire as is in the sick for health - such a desire as is in Women for their Husbands that are beyond sea, an earnest desire. ...

... it is a desire that is lasting, and continued.... where there is desire of a thing, there is hope, and it will make them hope to the end, when it lasts to the end. . . ${ }^{60}$

Women, the sick and the enslaved here serve as indexes of longing in relations structurally determined by the irresistible, constant and constitutive force of their desires.

For a prophet such as Trapnel, the troping of free grace as a state of both desire and satiation has a particular resonance and aptness, for prophecy might itself be described as a discourse of desire, comprising as it does an interpretation of that which already is (the bible, contemporary events and people, dreams and visions) in order to figure a projected future. For Fifth Monarchists, in particular, that which was to come was also that which was longed for - namely, the bodily return of King Jesus, precipitating the millennium and the Rule of the Saints. A desire for a particular future was thus fundamental to their political programme, and the discourse of free grace offered a doctrinally sanctioned language through which to articulate 
that longing, a language that at once erased the corrupt body of the unsanctified and replaced it with the transformed and sated body of the saint dwelling in grace. ${ }^{61}$

The too-literal appropriation of such a discourse by radical sectaries, however, was not without its dangers. In the notorious case of William Franklin and Mary Gadbury, who claimed respectively to be the returned Christ and his spouse, the couple were condemned for their blasphemous and licentious application of biblical figures as justification for their adultery, "the man forsaking his wife and children to accompany himself with another woman, and she as much embracing him, and selling all to follow him, as her Lord and Christ":

Hence it was I suppose, that as he was proclaimed by her to be the Christ, so she declared of her self, and was acknowledged by their seduced Followers, to be the Spouse of Christ; and she blasphemously to apply to her self the Scripture of the Lambs marriage being come, and his Bride to have made her self ready. . . . Thus is Franklin now in the room of Christ to her, he taking to himself what is proper to Christ; and she putting her self in the room of the Church, Christs mystical body, to be the Spouse of Christ, the Bride, the Lambs wife. ${ }^{62}$

Franklin, like Trapnel, claimed to have a body renewed in Christ; as a result, he claimed, the old body and its identities and responsibilities were destroyed: "And as for the Woman his Wife, he owned her so to be his wife, while he carryed about that body, in which he was so joyned to her ... but now they were no more to him then any other woman and children, and that he had a Command from God to separate from her. . ."63 In the light of such cases, it becomes all too obvious why Trapnel would seek to distance herself from antinomianism and its imputed licentiousness. Instances such as that of Franklin and Gadbury, in which the spiritual body is elided with the physical body such that the superseding of spiritual Law becomes the flouting of the social law, expose all too clearly the dangers for Trapnel of claiming a body remade by Grace. The risk was that the biblical underpinning of such a claim would be undone by the social infractions undertaken on its authority - whether adultery and blasphemy, as with Franklin and Gadbury, or ecstatic and political prophecy, as with Trapnel.

Free grace functions as a powerful discursive agent in Trapnel's prophetic writings in no small part precisely because it is such a mobile and malleable concept. Its invocation is in some senses entirely conventional and unexceptionable, common to Arminians and antinomians, and to all shades of Calvinism in between, and this conventionality may at first seem to deny it any particular significance in Trapnel's textual manoeuvres. However, when we examine the terms in which the concept is figured in her texts, its 
importance in Trapnel's discursive armoury begins to emerge. Grace, as Purkiss has argued, erases the corrupt body, thereby dissolving the most insistent sign and marker of women's cultural inferiority. More than this, however, as the sanctification of the believer through grace brings with it the imputation of Christ's righteousness, the saint is remade in a body no longer corrupted by sin, and thus in a body whose desires and appetites are no longer reducible to signs of sinfulness; these too are remade within the new paradigm of grace, so that, in Trapnel's formulations, a desire that is structurally and textually marked as feminine can be imagined as both corporeal and godly, the ecstasy of its anticipated and assured satisfaction repeatedly rehearsed through her prophetic projections and her autobiographical self-inscriptions. The corrupt body might fall away at the moment of sanctification, leaving a space which can be inhabited by the divine voice, but this also leaves a space for the newly imagined body, the revived and sanctified body, to fill. Life under the gospel is spiritual, but not disembodied; the materiality of that state of grace is apparent in the Fifth Monarchist insistence on preparing for the bodily return of King Jesus. For Trapnel, God's free grace frees the self from this body, certainly, but not from the impetuses of desire and appetite, and these remain imaginable only through a well-established, biblically generated repertoire of images of material abundance and corporeal satisfaction. Moreover, through free grace - not earned, not merited, and not conditional - the state of being undeserving ceases to be a hindrance to the satisfaction of one's desires. Instead, the abandonment of any striving for merit, and with it any sense of control over one's own spiritual destiny, becomes the necessary precondition for the possible (though not inevitable) satisfaction of those desires. Grace is built on a premise of unworthiness, and turns it into the foundation of salvation. When this principle is considered in the context of the female prophet's claims to authority, its importance immediately becomes apparent. It not only reiterates the Pauline paradox that the last shall be first but it embraces the abjection of the self, and transvalues it as the glorious ground of the accession to grace.

\section{Notes}

Thanks for reading and commenting on earlier drafts of this article go to Alison Findlay, Jackie Stacey and Susan Wiseman, and to the editors of this issue, Elizabeth Sauer and Jennifer Andersen.

1. Anna Trapnel, A Legacy for Saints (London: Thomas Brewster, 1654), p. 15.

2. Four texts attributed to Anna Trapnel were published in 1654: Strange and Wonderful Newes from Whitehall (London: Robert Sele), The Cry of a Stone (London), A Legacy for Saints (London: Thomas Brewster), and Anna Trapnel's Report and Plea (London: 
132 / Renaissance and Reformation / Renaissance et Réforme

Thomas Brewster). The first two of these recount her Whitehall prophecies of January that year, and the last gives the fullest account of events subsequent to the Whitehall prophecies. Trapnel's later publications are A Voice for the King of Saints (London, 1657) and a 1000-page folio without a title page, held by the Bodleian Library, Oxford. Brief biographical accounts of Trapnel's life and work can be found in Richard L. Greaves and Robert Zaller, eds., Biographical Dictionary of British Radicals in the Seventeenth Century, 3 vols. (Brighton: Harvester, 1982-84), and in Maureen Bell, George Parfitt, and Simon Shepherd, A Biographical Dictionary of English Women Writers 1580-1720 (London: Harvester Wheatsheaf, 1990). Quotations from Trapnel's writings are all taken from the original publications, except in the case of The Cry of a Stone, where I use a new edition: Anna Trapnel, The Cry of a Stone, ed. and introd. Hilary Hinds (Tempe: Arizona Center for Medieval and Renaissance Studies, 2000).

3. An important exception is Esther Gilman Richey, The Politics of Revelation in the English Renaissance (Columbia: University of Missouri Press, 1998). Richey places Trapnel's prophecies on a continuum with more mainstream literary engagements with the phenomena of prophecy, revelation and apocalypse, and assesses their political engagement from this perspective.

4. For a full account of twentieth-century criticism of Trapnel, see the introduction to my edition of Trapnel's The Cry of a Stone, pp. xxxvi-xlvii.

5. As with other religious nomenclature from the seventeenth century (the most debated term is undoubtedly "Puritan"), the terms Arminianism, Calvinism and antinomianism are hard to assign fixed or comprehensive meanings to, since the last of these and, by the $1640 \mathrm{~s}$ at least, the first were used as pejorative terms by writers eager to dissociate themselves from particular doctrinal positions. Arminianism describes those who, following the Dutch theologian Jacobus Arminius, retained a belief that human choice and human will played a part in matters of salvation; it was therefore opposed to Calvinism, which rested on the tenets of absolute and unconditional predestination and election, with salvation being purely the effect of God's gift of grace, rather than of human merit, will, or desire. Antinomianism forcefully reasserted the primacy of faith over works, in opposition not only to Arminianism but also to a sense that, in the 1640s, more orthodox Calvinism was retreating from a full reliance on faith alone, instead tempering it with notions of piety and hence of "will" and "works." The term "antinomian" ("against law") indicates the absolute character of the state of grace in which the elect dwelt, a state that supersedes life under the Law. The Ranters thus constituted one (heretical) extrapolation of the antinomian position, believing that election, and life under the Gospel, freed Christians from the obligation to keep the moral law. Quakers, in contrast, adopted an extreme Arminian position, altogether rejecting Calvinist-derived notions of election and declaring instead that men and women needed only to turn to the Inward Light within them in order to be saved. For an exhaustive study of debates about and within Calvinism, see John von Rohr, The Covenant of Grace in Puritan Thought (Atlanta, GA: Scholars Press, 1986); an invaluable discussion of antinomianism and political debate in the 1640s in the context of the army can be found in Leo Solt, Saints in Arms: Puritanism and Democracy in Cromwell's Army (Stanford, CA: Stanford University Press, 1959); and lucid accounts of the debates about election and predestination in Protestant England are offered in Dewey D. Wallace, Jr., "The Doctrine of Predestination in the Early English Reformation," Church History 43 (1974): 201-15, and Dewey D. Wallace, Jr., Puritans and Predestination: Grace in English Protestant Theology, 1525-1695 (Chapel Hill: University of North Carolina Press, 1982). See, too, R. T. Kendall, Calvin and Calvinism to 1649 
Hilary Hinds / Anna Trapnel and the Gendered Politics of Free Grace / 133

(Oxford: Oxford University Press, 1979), and Ernest F. Kevan, The Grace of Law: A Study in Puritan Theology (London: Carey Kingsgate Press, 1964).

6. A useful collection comprising key articles that debate, amongst other things, the place that religious controversy had in the events leading to the civil wars of the 1640 s, is Margo Todd, ed., Reformation to Revolution: Politics and Religion in Early Modern England (London: Routledge, 1995). In that collection, see, in particular, Nicholas Tyacke, "Puritanism, Arminianism and Counter-Revolution," pp. 53-70, who argues that it was the turn to Arminianism by the Church of England under Archbishop Laud in the 1630s that caused the wars of religion of the 1640s; Peter White, "The Via Media in the Early Stuart Church," pp. 78-94, who argues against a polarity between Arminian and Calvinist; and Peter Lake, "Calvinism and the English Church 1570-1635," pp. 179-207, who looks at the place of different kinds of Calvinism (what he calls "experimental predestinarians" and "credal predestinarians") in the course of these events. See, too, Patrick Collinson, The Religion of Protestants: The Church in English Society 1559-1625 (Oxford: Clarendon Press, 1983), and Conrad Russell, The Causes of the English Civil War (Oxford: Clarendon Press, 1990). On the growth of the sects and radical religion during the 1640s, see Christopher Hill, The World Turned Upside Down: Radical Ideas during the English Revolution (London: Maurice Temple Smith, 1972), Murray Tolmie, The Triumph of the Saints: The Separate Churches of London 1616-1649 (Cambridge: Cambridge University Press, 1977), and J. F. McGregor and B. Reay, eds., Radical Religion in the English Revolution (Oxford: Oxford University Press, 1984).

7. Wallace, Puritans and Predestination, p. viii.

8. Wallace, "Doctrine of Predestination," p. 203. Justification and sanctification were stages in the journey towards salvation: "in justification one is freed from guilt, whereas in sanctification one is freed from corruption. The one is based on an act of God from 'without us,' while the other is based on an act of God 'within us.' In the former one benefits from imputed righteousness, in the latter from a gift of inherent righteousness. In justification one is accepted by God and given title to God's Kingdom, whereas in sanctification one is morally renewed by God and fitted for God's Kingdom" (von Rohr, pp. 92-93). See also Wallace, Puritans and Predestination, pp. 49-52. On debates about justification and sanctification between different tendencies within Puritanism, see von Rohr, pp. 92-115.

9. Wallace, "Doctrine of Predestination," pp. 212, 211.

10. von Rohr, p. 4.

11. Tyacke, "Puritanism, Arminianism and Counter-Revolution," p. 62.

12. J. F. McGregor, "The Baptists: Fount of All Heresy," in McGregor and Reay, eds., p. 28. On the Particular and General Baptists, see also Tolmie, pp. 50-84.

13. McGregor, "The Baptists," p. 59.

14. John Saltmarsh, Free Grace: or the Flowings of Christs Blood free to Sinners, 2nd ed. (London: Giles Calvert, 1646), sig. A5v .

15. Saltmarsh himself, however, seeks to dissociate himself from the name "antinomian"; see "An Occasional Word," a dedicatory epistle prefacing Free Grace, sig. A6 ${ }^{\mathrm{v}}$. For a statement of his position regarding the imputation of Christ's righteousness, see sig. ${ }^{A} 6^{r}$.

16. von Rohr, pp. 7-8; see also pp. 54 and 111. 
134 / Renaissance and Reformation / Renaissance et Réforme

17. Thomas Gataker, Antinomianism Discovered and Confuted: and Free Grace as it is held forth in Gods Word (London: T. R. and E. M., 1652), pp. 25-26.

18. Thomas Lambe, The Fountaine of Free Grace Opened By Questions and Answeres, 2nd ed. (London: Giles Calvert, 1648). There is some controversy as to the authorship of this pamphlet. It is attributed to the antinomian John Saltmarsh by Donald Wing in the Short Title Catalogue (New York: Modern Language Association of America, 1994-98), and by Wallace in Puritans and Predestination. However Tolmie argues persuasively that, on the basis of the views expressed here, the author is actually the General Baptist soap-boiler Thomas Lambe; see Tolmie, pp. 72 and 212, n. 7. Greaves and Zaller draw the same conclusion (2: 165).

19. Tolmie, p. 72.

20. Lambe, p. 15.

21. John Goodwin, The Remedie of Unreasonableness, or the Substance of a Speech Intended at a Conference or Dispute, In Al-hallows the Great, London, February 11, 1649 (London: John Macock, 1650). For accounts of these debates, see also John Graunt, A right Use made by a Stander by at the two Disputations at Great All-hallowes; between Mr Goodwin and Mr Symson, the 14 of January and 11 of February 1649 (London: M. Simmons for John Hancock, 1649), and William Hartley, Good News to all People, Glad Tydings for all Men (London: John Macock for Lodowick Lloyd and Henry Cripps, 1650), p. 32. These writers were using the old-style calendar, according to which the new year began on 25 March. The debates took place in January and February 1650 (new style).

22. Wallace, Puritans and Predestination, p. 119.

23. John Goodwin, Remedie of Unreasonableness, title p., p. 6.

24. The Fifth Monarchists are notoriously difficult to locate in relation to particular religious groupings or doctrinal positions. B. S. Capp (Fifth Monarchy Men [London: Faber, 1972], p. 172) writes that "[t]he Fifth Monarchists were a sect, albeit an amorphous one, though their genesis was political rather than religious." They were drawn principally from the Independents and Particular Baptists, and Fifth Monarchist groups continued within Baptist and Independent congregations. Capp argues that they differed from these groups "only in certain details of eschatology, and in their political attitude. But they saw themselves as a distinct group . . . and their meetings had a religious as well as a political function."

25. Trapnel, Legacy, p. 8. Trapnel moves freely between the old-and new-style calendars, at times conflating them in one date. Here, for example, she calls January "the first moneth" (new style) but names the year as 1642, which must be according to the old-style calendar, since in 1642 (new style), 1 January was a Saturday, whilst Trapnel notes that on the day of her conversion it fell on a Sunday ("first day"). 1 January 1643 (new style) did, however, fall on a Sunday.

26. See Trapnel, Report and Plea, p. 3, and Legacy, pp. 57-60.

27. Capp, pp. 179-82.

28. Most critics discuss The Cry of a Stone, Anna Trapnels Report and Plea, and Strange and Wonderful Newes, though Diane Purkiss addresses A Voice for the King of Saints in "Producing the Voice, Consuming the Body: Women Prophets of the Seventeenth Century," in Women, Writing, History 1640-1740, ed. Isobel Grundy and Susan Wiseman (London: Batsford, 1992), pp. 139-58. 
Hilary Hinds / Anna Trapnel and the Gendered Politics of Free Grace / 135

29. Trapnel, Legacy, p. 6; she makes a similar claim on page 13. It is noteworthy, too, that the Baptist writer Jane Turner makes the same point in very similar terms: "whereas formerly I thought that to receive such a principle was the ready way to be loose and carnal, I did believe that as justification and sanctification are inseparable . . . so the power of grace was more strong and able to keep me from sin, than all the legal bands and slavish fears in the world" (Jane Turner, Choice Experiences of the kind dealings of God before, in, and after Conversion [London: H. Hils, 1653], pp. 60-61; see also pp. 66-67).

30. Trapnel, Legacy, p. 28.

31. Ibid., pp. 14-15. The word "Antinomian" is misspelt in the text, but corrected in the Errata. On Simpson's antinomianism, see Tolmie, p. 109.

32. Trapnel distances herself from Familism in Cry, pp. 12, 62, and, by implication, from the Quakers in Cry, pp. 40, 62. Fifth Monarchists were quick to speak out against Quakerism, Christopher Feake and John Simpson co-signing the preface to the antiQuaker A Faithful Discovery of a Treacherous Design of Mystical Antichrist . . . Containing an Examination of many Doctrines of the People Called Quakers (London: H. Hills for Thomas Brewster, 1653), at a time when Quakerism was still a significant presence only in the north of England. Since most Fifth Monarchists were predestinarian Calvinists, they objected to the Quaker insistence on the saving grace of the Inward Light residing within everyone.

33. For a useful recent discussion of the range of kinds and meanings of "prophecy" in the seventeenth century, see Elaine Hobby, "Prophecy," in Anita Pacheco, ed., A Companion to Early Modern Women's Writing (Oxford: Blackwell, 2002), pp. 264-81.

34. Trapnel, Legacy, p. 9. The imputation of Christ's righteousness refers to "the attributing to believers of the righteousness of Christ, and to Christ of human sin, by vicarious substitution" $(O E D)$.

35. Trapnel, Legacy, pp. 12, 13, 14.

36. Ibid., pp. 43-47.

37. The title page of Cry identifies Trapnel as being in "the visions of God."

38. Trapnel, Cry, p. 45. Discussions of sectarian women writers' relationship to agency include Phyllis Mack, "Women as Prophets during the English Civil War," Feminist Studies 8.1 (1982): 19-45; Elaine Hobby, Virtue of Necessity: English Women's Writing 1649-1688 (London: Virago, 1988); Phyllis Mack, Visionary Women: Ecstatic Prophecy in Seventeenth-Century England (Berkeley: University of California Press, 1992); Sue Wiseman, "Unsilent Instruments and the Devil's Cushions: Authority in Seventeenth-Century Women's Prophetic Discourse," in New Feminist Discourses: Critical Essays on Theories and Texts, ed. Isobel Armstrong (London: Routledge: 1992), pp. 176-96; Elaine Hobby, “'Discourse so unsavoury': Women's Published Writings of the 1650s," in Grundy and Wiseman, eds., pp. 16-32; Purkiss; and Hilary Hinds, God's Englishwomen: Seventeenth-Century Radical Sectarian Writing and Feminist Criticism (Manchester: Manchester University Press, 1996).

39. Solt, p. 34.

40. Purkiss, pp. 149, 158. For an extended analysis of female fasting, see Nancy A. Gutierrez, "Shall she famish then?": Female Food Refusal in Early Modern England (Aldershot: Ashgate, 2003), and for a fascinating and seminal study of the issue in the medieval period, see Caroline Walker Bynum, Holy Feast and Holy Fast: The Relig- 
136 / Renaissance and Reformation / Renaissance et Réforme

ious Significance of Food to Medieval Women (Berkeley: University of California Press, 1987).

41. Trapnel, Cry, pp. 77, 48.

42. Trapnel, Legacy, p. 15.

43. Ibid., p. 28.

44. Ibid., p. 29.

45. Trapnel, Cry, p. 48

46. Trapnel, Legacy, p. 7.

47. For fascinating discussions of the "divine signification" of the body — specifically, the ways in which the physicality of the female body signified a relation with the incarnate Christ - in the work of medieval women writers, see Caroline Walker Bynum, "Women Mystics and Eucharistic Devotion in the Thirteenth Century" and "'. . . And Woman His Humanity': Female Imagery in the Religious Writing of the Later Middle Ages," in her book Fragmentation and Redemption: Essays on Gender and the Human Body in Medieval Religion (New York: Zone Books, 1991), pp. 119-50, 151-80.

48. Trapnel, Legacy, p. 29.

49. On the stages of the Ordo Salutis, see von Rohr, pp. 87-112.

50. Trapnel, Legacy, p. 16.

51. For an important discussion of early modern women's writing that bases a key element of its argument on this point, see Sharon Achinstein, "Romance of the Spirit: Female Sexuality and Religious Desire in Early Modern England," ELH 69 (2002): 413-38; she discusses the Song of Songs as allegory on p. 428.

52. On other women visionaries' use of the Song of Songs, see Barbara Newman, Sister of Wisdom: St. Hildegard's Theology of the Feminine (Berkeley: University of California Press, 1987), pp. 65-66; Bynum, Holy Feast, pp. 150-55; and Alison Weber, Teresa of Avila and the Rhetoric of Femininity (Princeton, NJ: Princeton University Press, 1990), pp. 111-22.

53. Trapnel, Legacy, p. 13. Trapnel draws here from Isaiah 25:6, Song of Songs 4:11 and 5:1, and from the Promised Land as described in Exodus 3:8.

54. Trapnel, Legacy, p. 64.

55. Achinstein, pp. 422-23.

56. For an analysis and critique of the concept of liminality (defined as "a moment of suspension of normal rules and roles, a crossing of boundaries and violating of norms, that enables us to understand those norms, even [or perhaps especially] when they conflict, and move on either to incorporate or reject them") see Caroline Walker Bynum, “Women's Stories, Women's Symbols: A Critique of Victor Turner's Theory of Liminality," in Fragmentation and Redemption, pp. 27-51; quotation from p. 30.

57. Contemporary commentaries on the Song of Songs include Henry Ainsworth, Annotations upon the five bookes of Moses, the booke of the Psalmes, and the Song of Songs, or, Canticles (London: M. Parsons for John Bellamie, 1639); John Trapp, Solomonis panaretos, or, A commentarie upon the books of Proverbs, Ecclesiastes, and the Song of Songs (London: T.R. and E.M. for John Bellamie, 1650); John Brayne, An exposition upon the Canticles, or Solomons song of songs (London: Robert Austin, 1651); John Mayer, A commentary upon the holy writings of Job, David, and Solomon (London: 
Hilary Hinds / Anna Trapnel and the Gendered Politics of Free Grace / 137

Richard Ibbitson and Thomas Roycroft, 1653); and William Guild, Loves entercours between the Lamb and his bride, Christ and his Church. Or, A clear explication and application of the Song of Solomon (London: W. Wilson for Ralph Smith, 1657).

58. William Greenhill, Sermons of Christ His Last Discovery of Himself (London: R.I. for Livewell Chapman, 1656), p. 73.

59. An historical analysis of the social structures and processes of courtship in sixteenthcentury England can be found in Diana O'Hara, Courtship and Constraint: Rethinking the Making of Marriage in Tudor England (Manchester: Manchester University Press, 2000). In the context of my argument here, it is interesting to note O'Hara's suggestion that "[c]ouples were especially likely to meet in 'liminal spaces' such as fairs, alehouses, marketplaces and less formal arenas like stiles and gates” (p. 239).

60. Greenhill, Sermons, pp. 68, 69.

61. Moreover, as noted above, Achinstein, p. 428, reminds us that the Song of Songs had conventionally been read not only as an allegory of Christ's love for his church, but also of the apocalypse foretold in Revelation - a particularly powerful combination for Trapnel as a Fifth Monarchist prophet.

62. Humphrey Ellis, Pseudochristus: Or, A true and faithful Relation of the Grand Impostures, Abominable Practises, Horrid Blasphemies, Gross Deceits; Lately spread abroad and acted in the County of Southampton, by William Frankelin and Mary Gadbury (London: 1650), pp. 13, 15-16.

63. Ibid., p. 11. 